\title{
Summary of Experience from the Long-Term Pedological Research on the Banks and Slopes of Lake Most
}

\author{
Petr Vráblík ${ }^{1}$, Michal Řehoř², Pavel Schmidt'², Eliška Wildová1 \\ ${ }^{1}$ Department of Natural Sciences, Faculty of Environment, J. E. Purkyně University in Ústí nad Labem, \\ Ústí nad Labem, Czech Republic \\ ${ }^{2}$ Research Institute for Brown Coal in Most, Most, Czech Republic \\ Email: Wildova.Eliska@gmail.com
}

How to cite this paper: Vráblík, P., Řehoř, M., Schmidt, P. and Wildová, E. (2018) Summary of Experience from the Long-Term Pedological Research on the Banks and Slopes of Lake Most. Open Journal of Soil Science, 8, 350-359.

https://doi.org/10.4236/ojss.2018.812025

Received: November 6, 2018

Accepted: December 22, 2018

Published: December 25, 2018

Copyright $\odot 2018$ by authors and Scientific Research Publishing Inc. This work is licensed under the Creative Commons Attribution International License (CC BY 4.0).

http://creativecommons.org/licenses/by/4.0/

\begin{abstract}
This paper briefly assesses the conclusions from the long-term research of soil properties of the banks and shore of Lake Most. This paper mainly deals with the long-term development of the soil parameters of the anthropogenic soil profile and, to a lesser extent, the assessment of soil habitats with a typical flora. The experience gained will aid in the planning of further hydrological reclamation.
\end{abstract}

\section{Keywords}

Hydrological Reclamation, Pedology, Long-Term Research, Soil Profile

\section{Introduction}

The history of brown coal mining and reclamation in today's Lake Most is long and interesting. There were several smaller underground mines already by the end of the 19th century. In 1921, the Prince Evžen surface mine was opened in the area of today's lake, and especially the Richard surface mine, which mined up to 875,000 tons per year in the 1920s. In 1945, the surface mine was incorporated under the name Ležáky into the national company Severočeské hnědouhelné doly. With the newly opened quarry, Most reached over 7 million tonnes of mining in the 1980s. The dark side of the mining was the liquidation of the historic town of Most and many municipalities. The mining of brown coal at the site ended in 1999.

The recovery work began after the decision to reduce the mining of brown coal in 1995 and accelerated after the mining operations closed down in 1999. 
This especially involved modifying the slopes of the future lake and securing of the bottom by sealing it with overlapping coal bed residues. Gradually, three layers of clay were spread out and compacted. In 2008, bank repairs, their reinforcement, and construction of $4 \mathrm{~m}$ wide peripheral road were completed. The construction and restoration work was followed by forestry and other (recreational purpose) reclamations of the banks and slopes. The filling itself of Lake Most by the inflow was started on 24/10/2008. The main source of water was the Ohře River. The water was supplied by the Nechranice industrial water main and the inflow from Stanná pod Nechranickou přehradou pumping station [1]. The second authorized source was the mine waters from the Kohinoor mine. The third source was the natural catchment area of the lake. The filling process was completed in autumn of 2014. This resulted in an area of 311 hectares and a maximum depth of $75 \mathrm{~m}$. The total volume of water reached 68.9 million $\mathrm{m}^{3}$ and the operating level at an altitude of $199 \mathrm{~m}$ could fluctuate by $0.3 \mathrm{~m}$. The history of mining and reclamation was described in detail earlier in this magazine [2].

The reclamation of the area of interest is the most extensive hydrological reclamation in the Czech Republic and the experience gained here will be used in the future to build further, substantially larger, lakes in the residual pits of surface mines [3]. Due to the extent and significance of this hydrological reclamation, a comprehensive research project of the Czech Republic's Technological Agency "Impacts on the microclimate, air quality, water and soil ecosystems in the reclamation of brown-coal quarries" took place between 2011-2014. An important part of the problem is also the pedological properties of the shores and the slopes of the lake. The overall results of the research are summarized in this article.

\section{A Brief Summary of the Results Achieved at the Time of the Solving the Project}

Upon the completion of the research work, the research was initiated by a field mapping of the area of interest with a probe rod. On the basis of this, the territory was divided into 3 relatively homogeneous units and a total of 9 characteristic sites were selected for the long-term sampling probes, from which soil samples were collected and analyzed twice a year. The results obtained evaluated the development of the soil profile properties. On the basis of the continuously running additional mapping of the individual areas, small phytotoxic areas and areas with small slides were mapped. Another problematic scope was assessing the properties of the soil habitats with a characteristic flora. Great attention was paid to the distribution of risk trace elements in the soil of the area, including phytotoxic areas. At the end of the research, a land map of the area was compiled, including explanatory notes.

\subsection{Methodology of Reconnaissance of the Terrain, Mapping and Laboratory Analysis Carried out between 2011-2014}

For the research area is characteristic a very changing climate in relation to the 
altitude. Temperatures and sunshine decrease with higher altitudes. For the basin part of the region there is a frequent occurrence of the inverse states. As a result of the rainfall shadow, the basin has lower cloud cover, low precipitation, and higher temperature fluctuations, making it closer to the continental climate. The temperature is annually stabilized in diameters of $5^{\circ} \mathrm{C}$ in the mountain range and $8^{\circ} \mathrm{C}-9^{\circ} \mathrm{C}$ in the basin. The average annual precipitation is around $500 \mathrm{~mm}$.

The reconnaissance of the terrain was carried out by soil punctures with the probe rod to a depth of $0.6 \mathrm{~m}$ of the soil profile throughout the area being assessed. Determining the number of punctures per hectare was dependent on the soil heterogeneity [4]. Taking soil samples was carried out from the exposed sides of the soil probe and only from horizons that were macroscopically different (grain size, color). The amount of soil collected for one sample was $1-1.5 \mathrm{~kg}$ if the soil skeleton in the soil was above $20 \%$, it increased to $3-5 \mathrm{~kg}$. The sampling points were recorded into the work maps. Photographs were always taken during the sampling. The mineralogical, physical-mechanical, chemical and pedological properties were evaluated in the samples [5]. All the carried out laboratory analyses were performed by VÚHU A.S. and VÚMOP V.V.I. accredited by the ČIA in accordance with the ČSN EN 150/IEC 17025 standard based on the internal methodologies that are based on relevant standards. For each specimen, the following procedures were carried out: grading determination, evaluation of the mineralogical composition on a Siemens X-ray diffractometer, determination of the soil reaction, determination of the $\mathrm{CaCO}_{3}$ content, determination of the content and quality of oxidizable carbon and humus, determination of the nitrogen and sulfur content, determination of the absorption capacity, determination of the acceptable nutrient content according to Melich III [4] and determining of the content of hazardous trace elements.

The situation of the partially filled lake with newly placed soil probes in 2011 is shown in Figure 1 below.

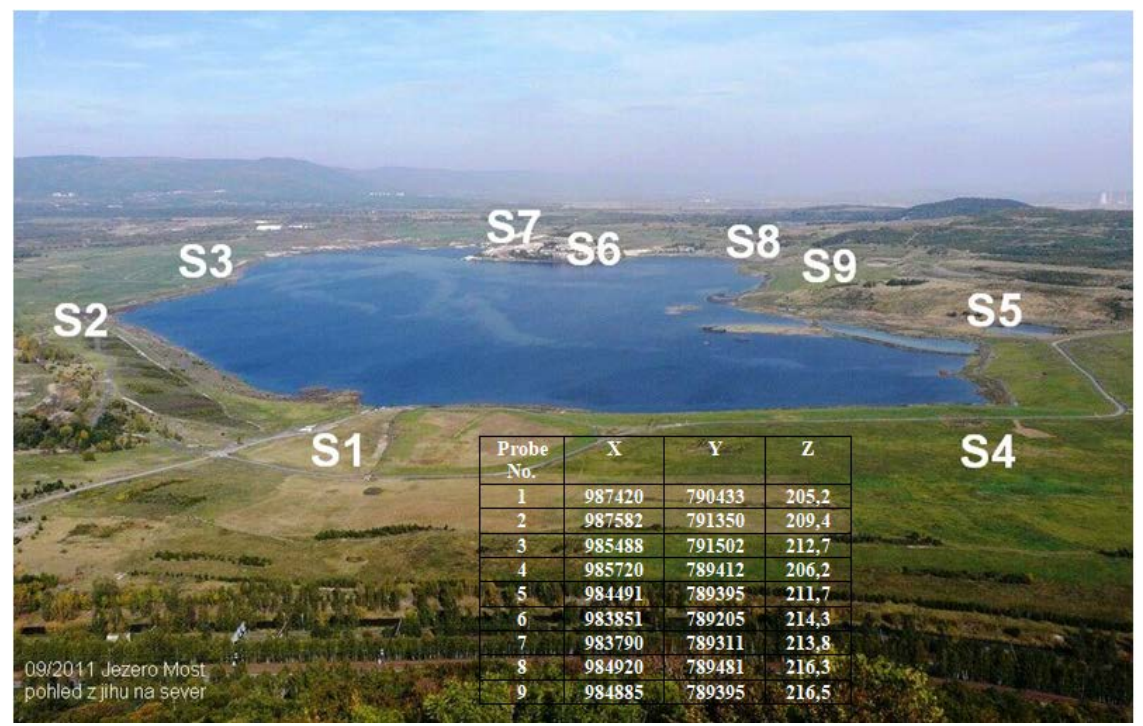

Figure 1. The situation of dug probes on the banks of Lake Most [2]. 


\subsection{Results of Resolving Individual Problem Sectors}

\subsubsection{Results of the Analysis of the Soil Horizon Changes When Resolving the Project}

In the first year of resolving, 9 sites with characteristic soils for long-term sampling and analysis of the soil horizon were selected on the basis of preliminary probe mapping. From these probes, samples of the soil were taken and analyzed seven times (once in 2011 and twice between 2012-2014). The sampling and the sample analysis followed the methodology described in Chapter 2.1 of this report. All the results achieved are presented in the project milestones from between 2011-2014 [6]. After four years of research, a very slow improvement of the chemical-pedologic soil parameters in the sampling probes (especially the content of the acceptable nutrients, partly even humus, absorption, total nitrogen) can be noted. No deterioration of the soil quality was found in any quantity. However, for a totally unambiguous conclusion on the evolution of the soil horizon, the observation period of 4 years is rather short. The results of the entry and the final sampling are given in Table 1 and Table 2.

Coordinates of the reconnaissance probes:

S1 (X-986 620, Y-791225), S2 (X-985 490, Y-791 290), S3 (X-984 865, Y-790 805), S4 (X-986 992, Y-790 505), S5 (X-986 554, Y-789 715), S6 (X-984 915, Y-789 715), S7 (X-984 685, Y-789 725), S8 (X-984 905, Y-785 195), S9 (X-985 210, Y-789 195).

\subsubsection{Results of the Monitoring of the Properties of the Soil Habitats with Characteristics Flora Resolving the Project}

After the first stage of the pedological and botanical mapping was completed, researchers were consulted and 11 botanically interesting sites were selected where the soil probes were excavated and samples were taken for a pedological

Table 1. Basic pedological parameters of the soil from the individual probes-sampling in September 2011.

\begin{tabular}{|c|c|c|c|c|c|c|c|c|c|c|}
\hline \multirow{3}{*}{ Rock type } & \multirow{3}{*}{ Nc (\%) } & \multirow{3}{*}{ org. substances Cox (\%) } & \multirow{3}{*}{$\mathrm{CaCO}_{3}(\%)$} & \multirow{3}{*}{$\mathrm{pH} \mathrm{KCl}$} & \multicolumn{3}{|c|}{ Acceptable nutrients $\left(\mathrm{mg} \cdot \mathrm{kg}^{-1}\right)$} & \multicolumn{3}{|c|}{ Absorption ability } \\
\hline & & & & & \multirow{2}{*}{$\mathrm{P}$} & \multirow{2}{*}{$\mathrm{K}$} & \multirow{2}{*}{$\mathrm{Mg}$} & S & $\mathrm{T}$ & \multirow{2}{*}{ V (\%) } \\
\hline & & & & & & & & \multicolumn{2}{|c|}{$\mathrm{mmol} / 100 \mathrm{~g}$} & \\
\hline S1 & 0.07 & 2.2 & 1.7 & 6.8 & 4 & 311 & 812 & 17 & 17 & 100 \\
\hline S2 & 0.05 & 2.4 & 1.8 & 7.0 & 3 & 295 & 763 & 15 & 15 & 100 \\
\hline S3 & 0.09 & 2.7 & 2.1 & 6.9 & 6 & 325 & 855 & 17 & 17 & 100 \\
\hline S4 & 0.07 & 1.9 & 1.7 & 6.7 & 3 & 256 & 711 & 15 & 15 & 100 \\
\hline S5 & 0.00 & 5.6 & 0.8 & 3.9 & 0 & 75 & 198 & 5 & 25 & 20 \\
\hline S6 & 0.00 & 0.0 & 0.4 & 7.1 & 1 & 95 & 211 & 3 & 3 & 100 \\
\hline S7 & 0.01 & 0.2 & 0.7 & 7.3 & 1 & 105 & 223 & 5 & 5 & 100 \\
\hline S8 & 0.08 & 3.3 & 2.0 & 6.8 & 4 & 265 & 724 & 17 & 17 & 100 \\
\hline S9 & 0.07 & 2.9 & 1.8 & 6.8 & 3 & 248 & 699 & 15 & 15 & 100 \\
\hline
\end{tabular}

S1-brown clay, S2-brown clay, S3-brown clay, S4-gray clay, S5-gray clay with coal matter, S6-phonolite gravel, S7-kaolinically weathered phonolite, S8-brown clay, S9-brown clay. 
analysis using the methodology described in Chapter 2.1. Most fieldwork and laboratory work took place between the years 2012-2013 [7]. Details of botanical habitats, the rationale for selecting them and the location of the individual habitats are given in the botanical results of the project solution. The latest results obtained and the very brief properties of the habitats are given in Table 3 below.

Table 2. Basic pedological parameters of the soil from the individual probes-sampling in September 2014.

\begin{tabular}{|c|c|c|c|c|c|c|c|c|c|c|}
\hline \multirow{3}{*}{ Probe/soil area } & \multirow{3}{*}{ Nc (\%) } & \multirow{3}{*}{$\begin{array}{l}\text { org. substances } \\
\text { Cox }(\%)\end{array}$} & \multirow{3}{*}{$\begin{array}{c}\mathrm{CaCO}_{3} \\
(\%)\end{array}$} & \multirow{3}{*}{$\begin{array}{l}\mathrm{pH} \\
\mathrm{KCl}\end{array}$} & \multicolumn{3}{|c|}{ Acceptable nutrients (mg. $\mathrm{kg}^{-1}$ ) } & \multicolumn{3}{|c|}{ Absorption ability } \\
\hline & & & & & \multirow{2}{*}{$\mathrm{P}$} & \multirow{2}{*}{$\mathrm{K}$} & \multirow{2}{*}{$\mathrm{Mg}$} & S & $\mathrm{T}$ & \multirow{2}{*}{$\mathrm{V}(\%)$} \\
\hline & & & & & & & & \multicolumn{2}{|c|}{$\mathrm{mmol} / 100 \mathrm{~g}$} & \\
\hline S1 (area 1) & 0.10 & 2.4 & 1.8 & 7.1 & 6 & 319 & 867 & 18 & 18 & 100 \\
\hline S2 (area 2) & 0.09 & 2.4 & 2.0 & 7.2 & 5 & 320 & 835 & 18 & 18 & 100 \\
\hline S3 (area 3) & 0.10 & 2.8 & 2.3 & 6.9 & 6 & 354 & 921 & 18 & 18 & 100 \\
\hline S4 (area 4) & 0.08 & 2.3 & 1.9 & 6.8 & 5 & 311 & 901 & 17 & 17 & 100 \\
\hline S5 (area 5) & 0.01 & 5.3 & 0.7 & 4.5 & 0 & 82 & 201 & 6 & 24 & 25 \\
\hline S6 (area 6) & 0.00 & 0.2 & 0.5 & 7.2 & 21 & 101 & 244 & 7 & 7 & 100 \\
\hline S7 (area 7) & 0.02 & 0.3 & 1.3 & 7.2 & 3 & 125 & 231 & 7 & 7 & 100 \\
\hline S8 (area 8) & 0.11 & 3.3 & 2.2 & 7.1 & 5 & 291 & 822 & 17 & 17 & 100 \\
\hline S9 (area 9) & 0.12 & 3.3 & 2.0 & 7.1 & 6 & 282 & 731 & 17 & 17 & 100 \\
\hline
\end{tabular}

S1-brown clay, S2-brown clay, S3-brown clay, S4-gray clay, S5-gray clay with coal matter, S6-phonolite gravel, S7-kaolinically weathered phonolite, S8-brown clay, S9-brown clay.

Table 3. Basic pedological parameters of the samples taken from the individual sites in 2012 (results of the 2013 analyses).

\begin{tabular}{|c|c|c|c|c|c|c|c|c|c|c|}
\hline \multirow{3}{*}{ Site } & \multirow{3}{*}{ Nc (\%) } & \multirow{3}{*}{$\begin{array}{l}\text { org. substances } \\
\text { Cox }(\%)\end{array}$} & \multirow{3}{*}{$\begin{array}{c}\mathrm{CaCO}_{3} \\
(\%)\end{array}$} & \multirow{3}{*}{$\begin{array}{l}\mathrm{pH} \\
\mathrm{KCl}\end{array}$} & \multicolumn{3}{|c|}{ Acceptable nutrients (mg. $\mathrm{kg}^{-1}$ ) } & \multicolumn{3}{|c|}{ Absorption ability } \\
\hline & & & & & \multirow{2}{*}{$\mathrm{P}$} & \multirow{2}{*}{$\mathrm{K}$} & \multirow{2}{*}{$\mathrm{Mg}$} & $S$ & $\mathrm{~T}$ & \multirow{2}{*}{$\mathrm{V}(\%)$} \\
\hline & & & & & & & & \multicolumn{2}{|c|}{$\mathrm{mmol} / 100 \mathrm{~g}$} & \\
\hline 1 & 0.05 & 1.8 & 1.3 & 6.7 & 2 & 232 & 618 & 14 & 14 & 100 \\
\hline 2 & 0.08 & 2.2 & 1.5 & 7.0 & 4 & 299 & 788 & 16 & 16 & 100 \\
\hline 3 & 0 & 4.4 & 0.2 & 4.0 & 1 & 89 & 122 & 5 & 25 & 20 \\
\hline 4 & 0.07 & 2.2 & 1.1 & 6.7 & 2 & 235 & 660 & 15 & 15 & 100 \\
\hline 5 & 0.04 & 1.9 & 0.7 & 6.6 & 2 & 289 & 658 & 14 & 14 & 100 \\
\hline $5 b$ & 0.06 & 2.1 & 1.3 & 6.8 & 3 & 298 & 745 & 15 & 15 & 100 \\
\hline 6 & 0.06 & 2.1 & 2.9 & 7.2 & 4 & 294 & 701 & 16 & 16 & 100 \\
\hline 7 & 0.04 & 1.9 & 3.0 & 7.2 & 2 & 246 & 663 & 14 & 14 & 100 \\
\hline 8 & 0.00 & 0.0 & 0.3 & 7.3 & 0 & 97 & 185 & 4 & 4 & 100 \\
\hline 9 & 0.01 & 0.3 & 0.4 & 7.3 & 1 & 105 & 225 & 6 & 6 & 100 \\
\hline 10 & 0.10 & 2.9 & 2.1 & 7.0 & 4 & 301 & 743 & 16 & 16 & 100 \\
\hline
\end{tabular}

Site 1-behind the gatehouse of the company, the initial succession stage; Site 2-reed slopel; Site 3-phytotoxic area over pond 1; Site 4-Pond shore 1; Site 5-Pond shore 2; Site 5b-Pond shore no. 3; Site 6-under the Celio, above the road. Soggy salt lake with a characteristic flora; Site 7-under the Celio, above the road. Dry salt lake with characteristic flora; Site 8-the slopes of Kočičí vrch; Site 9-the slopes of Kočičí vrch; Site 10-Pařidelský lalok (the area with an application of organic matter from Štětí). 
In this case, a very slight improvement of the soil properties can be observed in the areas with brown clay (including the "wet" salt lake), partly in the Kočičí vrch area. However, it is only an indicative assessment, only 2 samples were taken within the horizon of only 2 years. The mineralogical composition has not changed since 2012, the presence of gypsum in probes 6 and 7 (salt lake vegetation) was confirmed. The results served as a basis for the botanical assessment of the area.

\subsubsection{Results of the Monitoring of the Occurrence of Hazardous Trace} Elements in the Soils of Lake Most during the Project Resolution

This important part of the project was carried out between the years 2012 and 2014. In the period between 2012-2013, sampling was carried out twice from 9 permanent site sampling probes and once of 15 small phytotoxic and sterile areas (see sub-reports from between 2012-2013). In 2014, an additional sampling of the selected typical phytotoxic and sterile surfaces took place. To preserve the continuity of the research, the methodology for the evaluation of the sediment of the Most basin which has been used since the 1990s (the determination of 2 mol/ $1 \mathrm{HNO}_{3}$ with the method of atomic absorption spectrometry) was maintained. The contents of the hazardous trace elements $\mathrm{As}, \mathrm{Be}, \mathrm{Cd}, \mathrm{Co}, \mathrm{Cr}, \mathrm{Cu}, \mathrm{Mo}$, $\mathrm{Ni}, \mathrm{Pb}, \mathrm{V}, \mathrm{Zn}, \mathrm{Hg}$ were compared with the background limits required for belonging to the agricultural land fund according to regulation 13/1994 Coll. The Limiting values of risk elements for forest soils are not set for conditions of the Czech Republic. The methodology of the laboratory analysis was guided by the relevant internal methodological procedure of the testing laboratory [8]. In addition, the results obtained in the area of lake Most were compared with the results obtained from the research of the old reclaimed dump in the Most basin [9] and with the results of the analyses of growing soils without anthropogenic influences (drilling the core near the Ore Mountains) [10]. The situation of the relatively most problematic areas of the lake Most area is shown in Table 4.

The most favorable results were obtained on the relatively young reclamations of the slope and shores of Lake Most where the contamination with hazardous trace elements is virtually not a problem. This is due to the relatively recent reclamation (the transfer from the atmosphere has been minimal), not using bentonites in the reclamation work and the relatively low geological background. The influence of the application of organic matter in the 1990s has not been proven. Slightly increased As content was found only in some small phytotoxic areas. Hazardous trace element contents are higher in phytotoxic soil than in the baseline sampling probes. A significant difference was found between the phytotoxic areas with coal matter and the sterile surfaces with increased siderite content. Increased levels of hazardous trace elements in coal-bearing soils are likely to cause the presence of iron sulfides and the products of their disintegration. No dangerous contents of the trace element were detected in any sample. In the case of the old reclaimed dumps, the problem of the soil profile reclaimed for agricultural purposes in some areas is only a very limited As content. Certain anomalies 
Table 4. Content of risk elements in the soil of phytotoxic and sterile areas (slopes of Lake Most-5/2014).

\begin{tabular}{ccccccc}
\hline \multirow{2}{*}{ Element } & \multicolumn{5}{c}{ Contents in sample ( mg. $\mathrm{kg}^{-1}$ ) } \\
\cline { 2 - 7 } & Surface 1 & Surface 2 & Surface 3 & Surface 4 & Surface 5 & Surface 6 \\
\hline Be & 3.1 & 10.5 & 5.3 & 14.1 & 4.1 & 1.9 \\
$\mathrm{Cd}$ & 1.53 & 1.32 & 0.75 & 1.65 & 0.95 & 0.11 \\
$\mathrm{Co}$ & 0.64 & 0.43 & 0.30 & 0.83 & 0.43 & 0.08 \\
$\mathrm{Cr}$ & 14.9 & 16.1 & 19.1 & 21.3 & 9.9 & 4.2 \\
$\mathrm{Cu}$ & 34.5 & 48.9 & 21.5 & 55.4 & 36.2 & 8.1 \\
$\mathrm{Hg}$ & - & 44.2 & 26.1 & 53.2 & 32.8 & 4.6 \\
$\mathrm{Mo}$ & 2.66 & 3.01 & 1.98 & 3.25 & 1.66 & 0.18 \\
$\mathrm{Ni}$ & 31.4 & 28.6 & 16.4 & 33.6 & 18.3 & 6.25 \\
$\mathrm{~Pb}$ & 28.6 & 35.2 & 22.5 & 46.8 & 32.8 & 9.3 \\
$\mathrm{~V}$ & 23.9 & 28.6 & 9.7 & 31.5 & 18.6 & 8.5 \\
$\mathrm{Zn}$ & 63.2 & 88.5 & 23.6 & 86.2 & 24.7 & 11.2 \\
\hline
\end{tabular}

in the above-limit content of some of the risk elements $(\mathrm{Co}, \mathrm{Cr}, \mathrm{Cu}, \mathrm{Ni}, \mathrm{V})$ in anthropo soil reclaimed for forestry purposes appear on the soils of reclaimed bentonites. On the non-layered soils of the coal seam, the As content increases locally. Due to the age of the reclamation, the transfer of toxic substances arising from the combustion of coal from the atmosphere into the pedosphere is significantly affected. In the case of the large overlying soil from a borehole near the Ore Mountains, the detected contents are below the limit values and exceed them only in isolated cases. Somewhat elevated is the As content, especially at a depth of up to $50 \mathrm{~m}$. The only source of the contamination is the natural geological setting.

\subsubsection{The Results of Mapping Work during the Project Resolution}

The mapping work was carried out throughout the entire task resolution, being the most important part of the pedological problem. The main result of the first phase of the work was dividing the shores and slopes of Lake Most into three main pedologic areas.

The First area (approximately $80 \%$ of the bank) forms kaolinitic-illitic brown clays suitable for reclamation. This is mostly the original soil; the western slopes are formed partly from the soil of the Střimice dump. Very small areas without vegetation appear locally in the area (their occurrence has been mapped). The cause is usually the occurrence of phytotoxic acidic soils of coal seams or less often, the occurrence of hard, siderites of enriched soils.

The second area (about $5 \%$ of the bank) consists of former mining aggregate (phonolite). It is made up of various eroded whitish phonolites, from practically solid gravel to kaolinically weathered soil. Reclaiming these soils is completely 
inappropriate; from the point of view of the landscape, the former quarry is an interesting phenomenon, which is recommended to leave a managed succession.

The third area (approximately $15 \%$ of the shore) is formed by the steep slopes of the Pařidelský Lobe. The soils here are similar to those of area 1 with the reclamation-appropriate kaolinite-illitic clays. However, due to the danger of erosion and landslides, organic materials from the former Štětí mill (decay bark and cellulosic sludge) were applied in the past as part of the technical reclamation [11].

In the first area, 5 long probes were dug, with 2 in the second probe region and 2 more probes in the third probe region. The probes were used to collect and analyze soil samples to monitor the changes in the soil horizon development (see Chapter 2.2.1). Further detailed mapping of the individual soil areas was carried out in the next stage of the research. Its aim was to specify the pedology of the individual areas and to find possible small isolated areas with different properties (especially phytotoxic). Due to the development of the stability situation between the years 2012-2013, attention was paid to new small slides and landslides. The result of this mapping stage was the discovery of up to 15 small phytotoxic areas and up to 17 tiny slides occurring in the individual pedological areas. The occurrences were measured and gradually plotted in the soil map. It is necessary to note that due to the long-term redevelopment and reclamation work, the number of phytotoxic areas and in particular the sloping areas is gradually changing, especially the stability situation has improved substantially in 2014 (redevelopment work is currently underway at the interface of pedological areas 2 and 3, 3 and 1. Within the research, phytotoxic areas have been given considerable space due to their properties, but their importance is minimal in terms of the reclamation because they do not represent $1 \%$ of the area under assessment.

\section{Conclusion}

As part of the pedologic solution of research task no. TA 01020592, a periodic monitoring of the soil profiles of 9 selected probes was carried out between the years 2011-2014; contamination with the risk trace elements in the areas of interest was surveyed, detailed mapping of the area was carried out, soil properties of the soil from 11 probes in interesting areas for the appearance of a remarkable flora and a land map of the area of interest with explanations was compiled. As part of the first area of resolving the pedologic problems, the sampling and analysis of the samples (once in 2011 and twice between the years 2012-2014) took place on the selected probes over four years. The results seem to result in a very slow improvement of the soil properties. However, for definitive conclusions, sampling is required over a longer period of time (see Chapter 2.2.1). The second area of research was the analysis of samples taken from probes at 11 botanically interesting sites. Samples were taken in 2012 and analyzed in 2013. The results presented in Chapter 2.2.2 served as a basis for the botanical part of the 
research. A great deal of attention was paid to the evaluation of the content of risk trace elements in the 9 selected probes. Samples were taken twice, and relatively risky phytotoxic areas were sampled in 2014. The results obtained were compared with the properties of the old reclaimed dumps and the properties of the growing soils taken from the borehole near the Ore Mountains. The properties of Lake Most are relatively the most favorable, due to the recent reclamation and the sufficient distance from the Ore Mountains. Detailed results are given in Chapter 2.2.3. The most important part of the pedologic issue was the mapping work which took place throughout the process of resolving the task. The main result of the first phase of the work was dividing the shores and slopes of Lake Most into three main pedologic areas. Further detailed mapping of the individual soil areas was carried out in the next stage of the research in order to clarify the pedology of the individual areas, to find small isolated phytotoxic areas (in total, making up less than $1 \%$ of the area) and small slopes and landslides. Detailed results are given in Chapter 2.2.4.

\section{Acknowledgements}

This article was supported by project QJ1520307 entitled "Sustainable Forms of Management in an Anthropogenically Burdened Region". This project was realized with financial support from state budget resources through the KUS program, Ministry of Agriculture of the Czech Republic.

\section{Conflicts of Interest}

The authors declare no conflicts of interest regarding the publication of this paper.

\section{References}

[1] Dvořák, P. and Švec, J. (2009) Filling of the Residual Mining Pit Most-Ležáky. Vesmír 88, s. 46, Prague.

[2] Řehoř, M. (2012) Geological and Pedological Characteristic of Lake Most Banks-The First Results. Zpravodaj Hnědé uhlí, 1/2012, Research Institute for Brown Coal, Most, 23-29.

[3] Řehoř, M., Šafářová, M. and Fraštia, M. (2014) Pedological Aspects of Large Hydrological Restoration of Former Open Pit Mine Ležáky/Most-New Results of Research. SGEM Conference Proceedings, 2, 207-214.

[4] Řehoř, M. (2007) Reclamation of Landscape Burdened by Brown Coal Mining with a Focus on Anthropogenic Soil Profiles Creation. Disertation Thesis, Ostrava.

[5] Čermák, P., Kohel, J. and Dedera, F. (1998) Reclamation of Areas Degraded by Mining Activities in North Bohemian Briwn Coal District. Methodology of the Research Institute for Soil and Water Conservation, Prague.

[6] Řehoř, M. (2014) Pedological Evaluation of Lake Most Soils-Periodical Reports 2011-2014, VÚHU a.s., 2011-2014.

[7] Řehoř, M., Šafářová, M. and Fraštia, M. (2013) Results of a Pedological Research of Lake Most in a Period from 2012 to 2013. Zpravodaj Hnědé uhlí, Most, 24-30. 
[8] Research Laboratory no. 1078 (2017) Internal Methodological Regulations ZL. Research Institute for Brown Coal, Most, IMP testing laboratories.

[9] Dedera, F. and Špiř́k, F. (1992) Report on the Monitoring and Evaluation of the Forest Pilot Operation at the Střrimická spoil tip_Ležáky I. Report of the Research Institute for Soil and Water Conservation, Prague.

[10] Řehoř, M., Čermák, P. and Schmidt, P. (2014) The Results of the Long-Term Research of the Risk Elements Contamination of Anthropogenic Soils Made during Brown Coal Mining. Zpravodaj Hnědé uhlí, 2/2014, Research Institute for Brown Coal, Most, 20-26.

[11] Čermák, P. (1992) Evaluation of Chemical Changes of the Spoil Tip Soil Reclaimed by Cellulosic Sludge. Expert Review, Research Institute for Soil and Water Conservation, Prague. 